The Acquisitions Librarian, (2003), v.15, n.30, pp.101-116.

Print ISSN: 1941-126X Online ISSN: 1941-1278

doi: 10.1300/J101v15n30_09

This is an electronic version of an article published in: Magda El-Sherbini (2003): Impact of Technical Services'

Policies on Access and Collection Development, The Acquisitions Librarian, 15:30, 101-116, is available online at: http://www.tandf.co.uk/journals/titles/1941126X.asp.

http://www.taylorandfrancisgroup.com/

http://www.tandfonline.com/doi/pdf/10.1300/J101v15n30_09

(O2003 by The Haworth Press, Inc. All rights reserved.

\title{
Impact of Technical Services' Policies on Access and Collection Development
}

\author{
Magda El-Sherbini
}

SUMMARY. This paper will put forth some ideas about how library technical services are dealing with "the information revolution" and what impact this has on library collections and access to them. An attempt is made here to survey some of the key factors which are contributing to the gradual redefinition of access, collections and technical services. These include the changing role of technical services and cataloging departments, the impact of electronic and digital materials on library acquisitions and processing, implications of applying national cataloging standards, local cataloging practices, book vendors and the use of their records in library catalogs, remote storage decisions, and the role that library schools play in educating new generations of cataloging professionals.

\section{INTRODUCTION}

It is entirely possible that nearly every article written during the last two decades on library issues begins with a statement about the changes taking place in libraries, the publishing industry or the web and about methods of disseminating information at the end of the XXth century. The information industry is undergoing a revolution and this is reflected in professional literature devoted to it. Attempting to describe the process, while being subjected to it, is a difficult undertaking.

Along with the changes in the information industry came the need to redefine some of the fundamental concepts of library management. These changes became manifest first in the ways in which libraries came to view cataloging and library collections and how these terms became redefined. As the library community left the comfortable world of print and fiche and moved into the realm of virtual text, it faced many issues. Some of those dealt with ownership. The term "acquisition" began to include the concept of "access" and sometimes be replaced by it. Without ownership, the whole process of cataloging, classifying and processing of materials came under scrutiny. Permanence of information, methods of access, and underlying technologies providing that access came to be viewed as more important than traditional cataloging and processing.

The library community had to respond quickly to the competition coming from the Internet and the virtual information industry. Significant portions of library budgets were diverted to this digital arena, and this is having a major impact on how the library collections are defined, treated

and accessed. Growing numbers of decision-makers in the library and information world maintain that paper is out and digital is in and that anything that is not current is not that relevant. Such one-sided tendencies have major implications for access. 
This paper will put forth some ideas about how library technical services are dealing with "the information revolution" and what impact this has on library collections and access to them. An attempt is made here to survey some of the key factors which are contributing to the gradual redefinition of access, collections and technical services. These include the changing role of technical services and cataloging departments, the impact of electronic and digital materials on library acquisitions and processing, implications of applying national cataloging standards, local cataloging practices, book vendors and the use of their records in library catalogs, remote storage decisions, and the role that library schools play in educating new generations of cataloging professionals.

\section{TECHNICAL SERVICES AND CATALOGING DEPARTMENTS}

Throughout the 1990s, many libraries came under continued financial pressure which had its origins in a variety of factors that impacted all aspects of the information industry. Rising costs of scientific publications, emergence of electronic publishing and high costs of providing adequate bibliographic access are just a few.

In the area of library technical services, budget limitations forced libraries to review their organizational structures and their policies governing library acquisition of materials as well as cataloging and processing of materials. Placed under financial constraints, library administrators looked for cost-saving techniques and tended to find them in their cataloging departments. According to Dorner "budget freezes or reductions and escalating costs have been part and parcel of library administration for the past two decades, and in most libraries, cataloging has borne much of brunt." 1

In making decisions to limit the amount of resources in technical services in general and cataloging departments in particular, library administrators tended to scrutinize the overall cost of processing of materials in libraries and base their decisions on these factors. Studies conducted at the time revealed that the cost of processing materials was excessively high. It was perceived that relatively low productivity of professional catalogers contributed to those statistics. As the pressure to cut costs and expedite processing continued to grow, experienced, long-term catalogers bore much of the blame for libraries' inability to cope with the demands of the changing information world and make quick decisions. Catalogers were charged with lacking imagination and resisting change. In his work on this subject Waite mentioned that "technical service organizations, especially our catalog department, have three features that do not mesh well with the new environment: they are expensive, they are slow, and they do not meet the information expectations for our customers." 2

Growing demands for greater access to materials and growing budget limitations coupled with the deteriorating image of catalogers, the high cost of cataloging, and the low productivity forced many administrators to rethink cataloging and their cataloging departments.

While cataloging and cataloging departments appeared to be in trouble and were not favored by library administrators, collections and collection development continued to grow as libraries acquired materials almost on the same pace as before. The budget cut or freeze did not have a proportionate effect on collection development and generally did not place restrictions on what libraries might buy. Although serials acquisition was somewhat curtailed, many new formats, including electronic, soon filled that void. 
Significant reductions in cataloging units coupled with pressure to keep pace with the demand for access to materials forced libraries to shift their policymaking and to look for solutions outside the library. One type of solution was found with vendor service providers who were eager to enter the marketplace and provide services for what constituted one of the core responsibilities of the library. Statistical surveys show that some academic libraries indicate that many vendors are being used for outsourcing of all or parts of their cataloging. ${ }^{3}$ Some libraries, such as Wright State University, eliminated their cataloging departments and outsourced the entire cataloging to OCLC TECHPRO. ${ }^{4}$ Other libraries re-engineered cataloging by using staff (non-MLS employees) to do cataloging. Other libraries took a different approach and applied streamlining and modifying the workflow to simplify and speed up the processing of their materials.

Ohio State University Libraries provide a good example of a library that faced these challenges by applying multiple approaches. The current Cataloging Department is not as comprehensive as it once was. During the last seven years the role of the department was redefined. For example, cataloging is currently being done successfully by non-professional staff and graduate students. ${ }^{5}$ Cataloging functions have been dispersed among several departments. For example, simple copy cataloging for English language materials is done in the Acquisitions Department (currently Monograph Department) and it is performed upon receipt. In addition, outsourcing was introduced and implemented successfully when the library lost several expert foreign language materials catalogers due to budget cuts. ${ }^{6}$ Cataloging had also implemented the PromptCat services to obtain cataloging records directly from a vendor. ${ }^{7}$ This multi-faceted approach allowed the library to deal with the budget crunch and continue providing access to most materials coming into the library.

All these changes had a major impact on the technical services training policy. Technical services had to change their training policy to meet the needs of the non-professional staff and graduate students who were now doing much of the cataloging. Special training had to be designed that would provide a combination of theory of cataloging as well as practice. Training also had to be focused on individual assignments to assure quality and understanding of the principles of cataloging. In some cases, cross training among high-level staff was necessary, especially when the library had limited staff.

Furthermore, the catalogers' role in the library changed from simply performing cataloging to "(1) providing leadership for bibliographic control activities in the library as well as in the profession, (2) creating the bibliographic access system for the library, (3) coordinating bibliographic access policies, (4) training, (5) managing a bibliographic access department or system, (6) innovating, (7) boundary-spanning, (8) evaluating the performance of the bibliographic access department or system, and (9) interpreting and conducting research.",

The role of technical service librarians is changing as they engage in mediation and become liaisons, communicating local cataloging and processing policies to their colleagues in the public service departments. Information brokers at the reference desk need to know how the mixed sources of cataloging impact access and what they are losing or gaining by these mixed sources of records. For example, when a library contracts all or part of cataloging to an external vendor, cataloging is done on the basis of specifications that are provided to the vendor. These specifications take into account contracting and workflow processes. Patrons' needs are usually taken into account when contracts are drawn up, but they tend not to be in the forefront of these considerations.

All of these changes in cataloging processes have a profound effect on access. With the lack of experienced in-house catalogers, much of cataloging is now delegated to non-professional 
catalogers, including students, or is being outsourced to external cataloging vendors. Results obtained from such mixed sources are not always reliable and contribute to the overall problem of record quality and access.

\section{ELECTRONIC AND DIGITAL MATERIALS AND THEIR IMPACT ON ACQUISITIONS BUDGETS}

Substantial changes taking place in academic and research libraries in the 1990s included budget reductions, spiraling costs of materials, introduction of new information and communication technologies and a general explosion of digital information. In order to respond to the information needs of their users and to keep pace with technological development in the information industry, libraries began to embrace the concept of the digital library. In broad terms, it means moving toward the concept of providing access to and bibliographic description for digital materials that the library may or may not own.

Initially, this meant investing in technical infrastructure and creating modest acquisitions budgets for digital materials. As this trend continued libraries were faced with the need to look at their operations and organizational structures. Changes in information availability and communication flows favored a trend to reorganize in an effort to meet the needs of the new, technologically savvy generation of library users in many instances, reorganization tended to favor a flattening of organizational structures.

Creating a virtual library and diverting significant parts of the materials budget to electronic resources had a profound impact on technical service organizations in general and cataloging departments in particular. Many cataloging units organized along traditional lines seemed unable to address the challenge of cataloging and processing of digital information. Grenci in her article discussed in detail the impact of web publishing on the organization of cataloging functions. In her study, she pointed out that "institutions that organize their cataloging function according to one of the traditional models are finding themselves increasingly unable to meet the demands being placed upon the new environment. Traditional models of organization can, and must be modified to successfully deal with this problem."

Libraries responded to this situation in a variety of ways. To meet the challenge of electronic publishing and digitization, some cataloging departments' functions were integrated with other technical service departments and new departments were formed. One of the models, applied at the Ohio State University Libraries, merged the Serials Section in the Cataloging Department with the Serials Acquisitions to form a new Serials and Electronic Resources Department. Other strategies would divert staff from departments that processed print materials to departments or units processing digital materials. This move could be easily implemented when positions became vacant. In one such example when the position of Coordinator of Western Languages Cataloging Section in the Cataloging Department became vacant, it was moved to the Serials and Electronic Resources Department to accommodate the workload increase in this area.

While this type of reorganization tended to favor the high profile digital collection processing it did not take into account the impact it would have on access to print materials. Traditional cataloging units continued to lose positions while their cataloging stream did not decrease.

As libraries focused their energies on addressing the needs of the digital information community, emphasis on processing of print materials along traditional models began to wane. 
Library administrators began to seek other alternatives, in part at least to compensate for this gap. Internal solutions involved using para-professional staff to do cataloging previously done by professional catalogers. In academic institutions, it often involved hiring part-time student assistants to perform these functions. Outsourcing of the work became a viable option as outside vendors began to offer ready cataloging records for new materials, or offer contract cataloging services.

Regardless of the impact of electronic resources and acquiring digital formats on cataloging or technical service organization, these materials need to be cataloged and made available to patrons. Cataloging them is not a miracle. Cataloging departments faced the challenge of providing access to materials in different formats for many years. Electronic resources should not be treated any differently then other formats and should not constitute a threat to functioning technical service units in most libraries.

The rules for cataloging apply equally to print and electronic formats. The decision to catalog them as a single record or multiple records is already clear and gives libraries much flexibility to apply these rules. The real challenge facing technical services is to make the selection policy for electronic resources coherent and clear and to articulate that the library does not have the responsibility to buy and catalog everything that is available on the web.

Many libraries today focus their attention on cataloging electronic resources, web sites, and virtual information sources. Shifts in materials budgets and reallocation of staff testify to this trend. This change of focus has a direct impact on purchasing and processing of printed materials. Although there is no evidence to suggest that there is a decrease in buying printed materials, there is substantial evidence of the tremendous increase in buying of digital materials.

\section{THE IMPACT OF APPLYING NATIONAL CATALOGING STANDARDS ON ACCESS}

Library literature has already addressed the importance of applying national cataloging standards and there are no arguments about the benefits of these standards. Organization of information according to Dewey or MARC is the backbone of library and information industry. Catalogers have been applying and will continue to apply these standards as they provide the users with access to the full range of research materials in all formats. They built a strong knowledge base and expertise in using AACR2, Library of Congress Rule Interpretations, Library of Congress Subject Headings, LC Subject Cataloging Manual, Library of Congress Classification, and the MARC (machine-readable cataloging) format for bibliographic data.

Applying national cataloging standards has a great impact on collection development and its use. Through national cataloging standards, libraries and bibliographic utilities (such as OCLC WorldCat and RLIN) are able to transmit knowledge about what information is held where, what subjects are covered, how much material is held in a collection, whether there are restrictions on use, origin of the records, and other physical and intellectual characteristics of the original source material.

What is new in the current discussion of standards is related to the newborn cataloging standards. The advent of electronic publishing gave rise to a proliferation of standards that are being applied to process and catalog information. OCLC Connexion, for example, is now

providing bibliographic records in MARC and Dublin Core standards. ${ }^{10}$ Both the user and the cataloger will definitely feel the impact of these changes. Today's catalogers are faced with a 
proliferation of new cataloging standards and have the choice and the flexibility to apply standards that are appropriate for each format.

As the new standards are being applied, technical service policies regarding cataloging have to be changed to reflect these new coming standards and to explain and educate their users, including acquisitions and reference librarians, on the use of these standards.

Multiple standards are not the only issues that have an effect on access. Change in the current standards and revised rules, such as AACR2 revised, MARC, LCSH, etc., also have an impact on maintaining consistency in the online databases and in access to information. Catalogers and information users need to be educated about the application of the new concepts of catalog records and how to deal with the new approaches to cataloging, especially for web and electronic resources.

Many library administrations tend to view the role of cataloging and applying national standards as diminishing in libraries. This approach is somewhat one-sided and not adequate to meet the information needs of tomorrow. Libraries need to invest not only in the acquisition of material, but also in the description and organization of those resources in shared formats. The Library of Congress' Program for Cooperative Cataloging (PCC) is one of the most successful programs for cataloging. It is an international cooperative effort aimed at expanding access to library collections by "providing useful, timely and cost-effective cataloging that meets mutually accepted standards of libraries around the world." name authority program), SACO (the subject authority program), BIBCO (the monographic bibliographic record program), and CONSER (the cooperative online series program).

By participating in this program, libraries will not only have access to local bibliographic records but also will increase the sharing and use of foreign bibliographic and authority records. This in particular will have a positive impact on acquisitions in general and acquiring foreign language materials in particular.

There are many discussions about whether to incorporate the cataloging of library web pages and Internet resources in the library catalog. Some libraries prefer to have a comprehensive catalog rather than having separate universes for traditional library resources and Internet resources. Authority control, subject access, and other cataloging standards should be applied to these resources. $^{12}$

\section{APPLYING LOCAL CATALOGING PRACTICES AND ITS IMPACT ON COLLECTIONS}

Many libraries apply local cataloging practices to describe certain collections or to shelflist materials in an alphabetical order, or to group materials by subject. Results of the decision to implement local practices have a great impact on access to collections and on collection development. At times, local practice decisions conflict with LC classification, making access to parts of collections difficult.

The Ohio State University Libraries have a long-standing tradition of applying local cataloging practices for shelflisting purposes. These local-cataloging practices have undergone numerous changes in the past ten years. Among these was the decision to eliminate paper shelflisting in the early 90 s and to discontinue shelflisting for all classes except classes M, N, and

Ps. ${ }^{13}$ At the same time, many other local practices have been applied to call numbers. These cataloging local practices are: adjusting call number for Classes M, N, and Ps; revised literature 
table 40 of class P; three (or more) cutters; OSU cuttering tables; OSU translation tables; adaptations, criticisms, etc.; editions and conferences; class " $Z$ " for bibliographies; prefixes and suffixes in call numbers.

There are two main reasons why OSU Libraries don't always follow LC:

- Local practice has been followed at OSUL for many years (e.g., Z8 for biography) and a number of records/books already exist with that number;

- Collection managers have requested a change in procedures (e.g., subject bibliographies in the subject classification number instead of in " $Z$ " class).

These local cataloging practices are now under review and a decision needs to be made whether OSUL should continue using them. There are clear advantages to eliminating cataloging local practices, consistency of cataloging being but one. At the same time however, eliminating local practice will have an impact on the traditional ways of accessing and using the collection.

1. Application of cataloging local practice allowed the library to maintain detailed information on what it owns, in what subject areas, and in what languages or by author. This was an advantage in the past when the online catalog was not available and users as well as collection mangers depended on open stacks to browse the collection and easily recognize the strength of the collection. With the elimination of local practice, the ability to browse the stacks by call number is limited. An argument can be made that with the advent of the online catalog and its capabilities, collection managers and users are now able to browse the collection through their OPAC and obtain this information electronically.

2. Elimination of local practice will produce inconsistencies in the call number assignments and in shelving materials in the stacks. This problem already exists, because of the history of shelflisting.

3. Applying local practice has proven to be expensive. Every record has to be checked against the shelflist and the call number had to be changed or modified to agree with the shelflist. This practice slows down the work and productivity.

4. Elimination of local practice will help reduce the cost of cataloging.

5. Elimination of local practice will allow member libraries to use each other's records in the OCLC database more effectively, (without making major changes) since all cataloging will conform to national standards.

6. Eliminating local cataloging practice will also allow the library to look at all the options available for providing bibliographic records, such as vendor record and shelf ready materials.

\section{VENDOR SERVICES AND THEIR IMPACT ON CATALOG RECORDS}

In the late 90s, OCLC and RLIN began to add to their database records created by foreign booksellers. This practice was accepted by libraries as a feasible alternative to cataloging in-house, but questions about the quality of records obtained from vendors became an issue. In his article on vendor records, Beall pointed out the impact of vendor records on cataloging and access in academic libraries. He mentioned in his analysis that "vendor records tend to be of very low 
bibliographic quality. They do not follow minimal-level cataloging and generally do not have authorized forms for names, series, and subject headings." 14

Questions regarding the quality of cataloging led academic libraries to direct their attention to vendor records and closely examine them. At OSUL, records from Harrasowitz are reviewed by catalogers and in most case are enhanced locally before they are added to the on-line catalog. Failure to follow such procedures could have posed a threat to the usability of the online catalog in the future. Since cataloging is done at OSUL by non-MLS catalogers, this work requires a great deal of time and in some cases slows down the workflow. Diverting resources to this process has a negative impact on original cataloging in that these materials are not processed upon receipt and as a result, they are not made available to patrons in a timely fashion.

Outsourcing can be an acceptable alternative to in-house cataloging, but it is fair to say that some catalog records obtained from vendors will not have the level of detail or accuracy that an in-house cataloger can provide. In-house catalogers have a combination of experience and much needed contact with the user. They can very easily identify what the users needs are and what kind of access they will look for. In addition, there is no limitation or restriction on how many fields need to be included in the bibliographic records. In contract cataloging the contractee has to set up a limit on how many subject headings will be in the bibliographic record, while in-house catalogers will add as many subject headings as are necessary to describe the content of materials.

\section{REMOTE LIBRARY STORAGE}

Many large academic and research libraries are using remote storage facilities to meet the need for shelving space created by the constant growth in library materials. Although remote storage has always been part of the solution to the problem of space in libraries, it seems to be more of a factor now, when so much emphasis in libraries is placed on instant access to materials. Why, then, is this becoming such a dilemma for libraries today? Are library materials budgets getting better? Is the cost of publishing decreasing? Regardless of the answer, moving selected materials to remote storage facilities is a fact of life for many libraries.

In his article on this topic, Seeds discussed some methods of de-selecting materials to be transferred to remote storage. He mentioned a number of factors which were considered in the de-selection process. These factors included duplicate materials, low usage, low circulation counts for monographs, amount of dust on materials, age of materials, foreign languages, poor condition, ceased and cancelled serial titles. ${ }^{15}$

Transferring of library materials to storage facilities has a great impact on access. One of the negative impacts on access is that the users of information can no longer walk into open stacks and browse the library collection. In addition, users sometimes have to wait for a long time for materials to arrive from storage. This in particular creates inconvenience to users and information seekers. Furthermore, the library collection is divided into the in-house collection and the off-site collection. This division makes it impossible for collection managers to scan the stacks to get a sense of what is in the collection. ${ }^{16}$

Housing some parts of the collection in remote storage facilities creates an unanticipated problem for the library administrator. As the volume of materials sent to storage increases, so does the need to provide better information in the bibliographic record. In order to guarantee good access to materials stored off-site, a full cataloging record has to be produced for those materials. Such a record might require the table of contents (TOC), more access points, such as additional 
authors, part of the title, and many subject headings. These enhancements help to provide valuable information for the item being stored remotely, making it accessible through the on-line catalog. This means allocating more resources to cataloging and increasing the number of qualified catalogers. This may be difficult to achieve at a time when library administrators are cutting back on cataloging and cataloger positions.

An argument could be made that the cause of these problems is the lack of a healthy collection development policy approach that is based on patrons needs. As Carrigan pointed out, "The collection development is responsible for making-up of the collections. The better job done matching the collections with the needs and interests of patrons, the greater will be the use of the collections, the attendant benefit, and thus the return on the investment in the collection."17

\section{LIBRARY SCHOOL'S IMPACT ON TECHNICAL SERVICES}

Library schools have always played a vital role in educating new generations of librarians who needed the knowledge of cataloging and classification theory and practice. As these professionals entered the work place, they benefited from the vast experience of senior catalogers who imparted their knowledge to the younger generation. This seemingly permanent symbiosis seems to be threatened by two trends that appear to be occurring simultaneously. The first is the continuous depletion of the ranks of senior experienced catalogers in libraries. The other is the flight of library school students from traditional cataloging courses in favor of technology driven curriculum.

Library technical service divisions in general and cataloging departments in particular are losing many experienced catalogers and technical staff as an entire generation of librarians considers retirement or leaves the profession. These positions are rarely, if ever, filled with staff of equal experience and expertise. Important cataloging knowledge is lost in the process as there is little opportunity to pass it on to the new generation. A recent email message indicated that the Cataloging Directorate of Library Services had lost 205 FTEs since 1990 and as a result they can no longer afford to perform quality cataloging because of insufficient professional staff. This situation has negative impact on the quality of cataloging. As a result, acquisitions and reference staff cannot adequately perform their duties when they can no longer rely on the accuracy of cataloging records. ${ }^{18}$

Library schools have a great role to play in the era of information processing. They always focused their attention on teaching curriculum to support the traditional functions of the libraries, such as management, technical services and public services. In teaching cataloging, library schools stressed the importance of the cataloging tools that were used in libraries to organize print and film collections.

Now, library schools are also supporting the fast development in technology and are devising ways in which the new librarian can meet the challenge provided by the diversity of the information industry. Schools have to develop courses that will impart the knowledge necessary in organizing information to meet today's information needs. In her presentation at the American Library Association Congress on Professional Education, Bates addressed the issue of the new challenges of processing digital formats when she said, "When it comes to cataloging, we need to prepare professionals who can recognize generic information description problems and translate them across all media. The AACR2 and Library of Congress Subject Headings will not do for all 
information in all environments. Our students need to be able to select an indexing language for a website's database, or develop an electronic finding list for an online archival collection."19

Catalogers and cataloging departments were the backbone of the library operations because of the important role they played in organizing information. In the early 1990s, catalogers began to experience tension brought about by the changes in their responsibility and felt that the important role they played in the past is diminishing. They also felt more pressure from the library administrators because of the nature of their detailed work. These developments eventually effected library schools and the role of cataloging in the curriculum. It seems that many students are no longer interested in cataloging jobs or cataloging courses because of the criticism that catalogers are facing. In addition, some library schools were no longer teaching cataloging and as Beacom said, ". . . we have counterexamples of good schools closing altogether." 20

As Turitz mentioned in his response to an email message related to teaching of cataloging, "Cataloging should be a requirement for graduation from library school (or information science as it is now often called). Even though the numbers of catalogers has gone down as more of it is outsourced and library schools no longer have cataloging as a requirement, we still need professionals who understand what decisions need to be made about the online catalog and what quality of cataloging/authority control. Etc." ${ }^{21}$

Library schools and library technical service units have a dual and complementary role to play in today's library. Beacom mentioned that "If library schools do not prepare students to add value to services and products in a networked information environment, then librarians - meaning "graduates of library schools" - will not be a part of scholarly communication." 22 And if technical services will not promote catalogers and redefine the role of catalogers in organizing information, the library profession will no longer have control over this function.

\section{CONCLUSION}

For some time now, library administrators are under significant pressure to reduce their costs and improve access to library materials. In attempting to deal with budget limitations, many look to cataloging departments to reduce their cost of operation. Having reduced their staff and with growing demands to catalog materials, they turned to third parties to help them provide access. Outsourcing services began to flourish, but the question of quality of their records and its impact on access remains unanswered.

All the while there is great pressure to produce high quality, expensive cataloging records. Libraries are committed to complex national cataloging standards, and ever changing local practices. They often have to contend with large parts of their collections being stored in remote locations and not easily accessible to users. Library policies are being changed to accommodate the need to provide access to the Internet and digital materials. As libraries overextend themselves to attain these goals, they continue to reduce their cataloging functions.

Technical service policies also play an important role in the cataloging function as a whole, as they impact the cataloger's job market tremendously. Elimination of cataloger's positions in libraries has lowered the total number of catalogers active in the profession. Many entry level (MLS) librarians with potential interest in cataloging are turning away from this option and shift their interest to public services positions as cataloging is perceived to be an unattractive and besieged part of the library organization. It is imperative for library technical services to take responsibility for redefining cataloging in light of the changes in the information processing 
industry. New job descriptions for catalogers have to meet today's needs and to attract new graduates, who are interested in organizing information and creating full-scale digital libraries. This will be possible if, as Beacom said ". . . they will only if library schools offer the right preparation: one that builds a foundation for growth in traditional library skills and the skills needed for the networked information environment."23

Finally, library administrators would do well to take another look at cataloging of library materials and come to terms with the fact that not every bit of cataloging is well served by alternative cataloging solutions. Cataloging today is becoming more complicated and requires enhanced professional skills to insure quality and accuracy in order for the users of tomorrow to get better access to library materials. Libraries also need to focus their attention on training a new generation of catalogers and provide them with new skills necessary to process materials according to national standards.

\section{REFERENCES}

1. Dorner, Dan. Cataloging in the 21st Century, Part 1: Contextual Issues. Library Collections \& Technical Services. Vol. 23, No. 4, 1999. Pp. 393-399.

2. Waite, Ellen J. Reinvent Catalogers! Library Journal. Vol. 120. (Nov. 1 1995). Pp. 36-7.

3. The Impact of Outsourcing and Privatization on Library Services and Management, http://www.ala.org/alaorg/ors/outsourcing/outsourcing_toc.html.

4. Hirshon, Arnold and Winters, Barbara. Outsourcing Library Technical Services: a How-To-Do It Manual For Librarians. New York, Neal-Schuman Publishers, Inc, 1996. 172 p.

5. El-Sherbini, Magda and Klim, George. Changes in Technical Services and Their Effect on the Role of Catalogers and Staff Education: An Overview. Cataloging \& Classification Quarterly. Vol. 24, No. 1/2. 1997. Pp. 23-33.

6. El-Sherbini, Magda. Contract Cataloging: a Pilot Project for Outsourcing Slavic Books. Cataloging \& Classification Quarterly Vol. 20, No. 3. 1995. Pp. 57-73.

7. Rider, Mary M. PromptCat: A Projected Service for Automatic Cataloging-Results of a Study at the Ohio University Libraries. Cataloging \& Classification Quarterly. Vol. 20, No. 4. 1995. Pp. 23-44.

8. Younger, Jennifer A. The Role of Librarians in Bibliographic Access Services in the 1990s. Journal of Library Administration. Vol. 15, No. 1/2. 1991. Pp.125-50.

9. Grenci, Mary. The Impact of Web Publishing on the Organization of Cataloging Functions. Library Collections, Acquisitions, and Technical Services. Vol. 24, Issue 2, summer, 2000. Pp. 153-170.

10. OCLC Connexion Web Page, http://www.oclc.org/connexion/.

11. Library of Congress. Program for Cooperative cataloging (PCC) web page, http://www.loc.gov/catdir/pcc/2001pcc.html.

12. University of California: System Wide Operations and Planning Advisory Committee (SOPAG). Electronic Resources Cataloging Task Force. 1998, http://tpot.ucsd.edu/ Cataloging/HotsElectronic/SOPAG/intro.htm.

13. El-Sherbini, Magda and Stalker John C. A Study of Cutter Number Adjustment at the Ohio State University Libraries. Library Resources \& Technical Services. Vol. 40, No. 4, October 1996. Pp. 319-326.

14. Beall, Jeffrey. The Impact of Vendor Records on Cataloging and Access in Academic Libraries. Library

Collections, Acquisitions, and Technical Services. Vol. 24, Issue 2, summer, 2000. Pp. 229-237.

15. Seeds, Robert S. Impact of Remote Library Storage on Information Consumers: "Sophie's Choice"? Collection Building. Vol. 19, No. 3. 2000. Pp. 105-108.

16. Ibid.

17. Carrigan, Dennis P. Toward a Theory of Collection Development. Library Acquisitions: Practice \& Theory. Vol. 19, No. 1. 1995. Pp. 97-106.

18. Statement of the Library of Congress Professional Guild, AFSCME Local 2910 Before the Committee on Appropriations Sub-Committee on Legislative Branch, Appropriation U.S House of Representatives. May 1, 2002, http://web.library.uiuc.edu/ahx/ead/ala/9701040a/berman/biblinks/loc.pdf.

19. Bates, Marcia J. Information Curriculum for the 21st Century. Revised as Presented to the American Library Association Congress on Professional Education. Washington, DC, May 1, 1999, 
20. Beacom, Matthew. The Catalog Librarian in the Age of the Smart Machine. A Presentation Given in 31 March 1996 at the Conference Finding Common Ground sponsored by the Harvard College Library. Cambridge, Massachusetts, http://www. library.yale.edu/ mbeacom./newbreed.htm.

21. Turitz, Mitch. Teaching Cataloging-One More Question. Online posting. 11 May 2000, http://innopacusers.org/list/archives/2000/msg01857.html.

22. Beacom, Matthew. The Catalog Librarian in the Age of the Smart Machine. A Presentation Given in 31 March 1996 at the Conference Finding Common Ground sponsored by the Harvard College Library. Cambridge, Massachusetts, http://www. library.yale.edu/ mbeacom./newbreed.htm.

23. Ibid. 